\title{
COMMUNICATION STRATEGIES USED BY EFL STUDENTS IN ENGLISH CLASSROOM SETTING
}

\author{
${ }^{\# 1}$ Arif Rahman, ${ }^{* 2}$ Dian Novia Isroyana \\ ${ }^{\# 1}$ English Lecturer, Graduated Program, Universitas Pendidikan Mandalika, Indonesia \\ ${ }^{* 2}$ English Teacher, SMK Selong, Indonesia \\ Corresponding Author Email: arifrahman058020@gmail.com
}

\begin{abstract}
A B S T RA C T S
The main objective of teaching English is to allow the learner to communicate orally and successfully. People all over the place study a foreign language to enable them to communicate effectively. This study investigates a phenomenon about communication strategy used by EFL students in English Classroom Setting. The focus of this study is to investigate the types of communication strategies and the most frequent types of communication strategies employed by EFL Students. It took place in Institut Pendidikan Nusantara Global that located in Central Lombok. The participant of this study was a total of 20 students from the second semester. A qualitative research design was used to collect the data need in this study embarrassing interviews and observation as main instruments; the observation used were field notes and videotape aimed to get the documentation of the study. The finding of the study shows that most of the students employed the types of communication strategy i.e.: Asking for clarification, requesting an explanation, asking for repetition, circumlocution, message abandonment, meaning negotiation, and interaction monitoring. Furthermore, the communication strategies frequently used by students i.e.: asking for clarification, message abandonment, and meaning negotiation. In conclusion, every student has their own communication strategy but the researcher categorized those strategies into several types.
\end{abstract}

\begin{tabular}{l}
\hline \multicolumn{1}{c}{ A R T I C L E I N F O } \\
\hline Article History: \\
Received: December, 2021
\end{tabular}

Revised: December, 2021

Published: December, 2021

\section{Keywords:}

Communication Strategy,

EFL Students,

English Class

How to cite: Rahman, A., \& Isroyana, D. (2021). Communication Strategies Used By EFL Students in English Classroom Setting. Jo-ELT (Journal of English Language Teaching) Fakultas Pendidikan Bahasa \& Seni Prodi Pendidikan Bahasa Inggris IKIP, 8(2), 207-217. doi:https://doi.org/10.33394/jo-elt.v8i2.4482

\section{INTRODUCTION}

Communication can be conveyed in the form of spoken, written, and others. Everything that humans use as a way to convey some message is called communication. When people communicate in spoken form, people definitely use a language to communicate. Language is known as a system of arbitrary conventionalized vocal, written, or gestural symbols that enable members of a given community to communicate intelligibly among other speakers and hearers (Brown \& Abeywickrama, 2019). It means that language is the way people communicate with others in various ways such as vocal, written, gestural, and symbols, by language people would easier to convey every message that would be delivered. Moreover, people should learn about language to make them easier to deliver the message to others.

In communication, English is one language that is used by people to communicate (Floreddu \& Cabiddu, 2016). English is one of the important languages in the world because English is the language that is used by every human as their language to communicate. In Indonesia, English become an important language to be mastered, starting from kindergarten 
up to university students learn English as their subject. English learns by many people in the world. It has also become a "lingua franca" among speakers of languages that are not mutually intelligible (Willis, 1996, and Mauranen, 2015). Furthermore, in the age of "globalism" we live nowadays, the interdependence of nations and countries creates a need for a global language and no language qualifies for this better than English (Abousenna, 1995: 15).

Many countries in the world learn English as their Foreign Language (FL). Especially in Indonesia, students still learn English as a Foreign Language (EFL). Indonesian use English as a Foreign Language because English is not their First Language (1L) but their (2L). In the fact, communicating using a Foreign language is the most problem. Many people hard to speak fluently with that language because rarely use the language (FL) and lack of communicative competence. Communicative competence is the general ability to use language accurately, appropriately, and flexibly (Yule, 2010: 194).

In the case of language teaching, communication also needs a strategy to make the respondent easier to grasp the message. The function of strategy in communication is to achieve a great language, which can be comprehended by own self and also the listeners. Moreover, the researcher expects students would be brave and confident in communication by using the strategy. Communication strategy is the technique used by humans to communicate with others. Tarone (1981: 287) explained that communication strategies can be viewed as the attempt of interlocutors to share meaningful communication through difficulties in the interlanguage system. By communication strategy, students feel more confident and able to speak in front of the classroom. As it is known, each student has a different strategy in communication. Therefore, the researcher is interested to investigate what kind of communication strategy is used by EFL students in English Classroom Setting.

Moreover, there are a lot of communication problems that happen in the real life. According to Sukmawati, (2016) who says that one of the commonly mentioned causes of reticence in the class is students' lack of confidence and fear of making mistakes and being laughed at. While based on the researcher review of the previous researcher there are some problems that often occur to the student in communication especially in oral communication is the students' less participation in the classroom caused the students' low achievement in speaking. Those are the problem that almost happens to tertiary students. If one of those problems happens to the students it may cause the student to lack in communication. Students cannot communicate fluently because of it. Therefore, communication strategy is take the main role in this case. Because with communication strategy students would feel more confident in communicating.

When the researcher conducted pre-observation in English Study Program of Institut Pendidikan Nusantara Global, The researcher found the problem that the students still lack of confidence and low participation. That problem was found after the researcher interviewed some of the lecturers on that faculty. Students are afraid when they speak, they were afraid if their friend taunts them if their communication was not good as others. Therefore, based on the overview above, the researcher intended to explore the communication strategy used by students in English Classroom Setting. This research was conducted to know how the students overcome the communication problem and to know the kind of communication strategy that is used by students when learning.

\section{RESEARCH METHOD \\ Research Design}

This study used qualitative research embracing Descriptive, this method is helpful for examining a variety of educational problems and issue Ary, Donald, Jacobs, Razavie, Asghar (2010) state that a descriptive study is designed to obtain information concerning the current 
status of phenomena". This method is chosen because the researcher would describe naturally the students and the teacher interaction in the classroom. In this case, this research aimed to analyze the students' communication strategy during the learning process. Moreover, the data, in this case, are described based on inductive formed which describe from specific to general

\section{Subject of the Study}

The subject or the participant in this research was 2nd-semester students of English Department of Institut Pendidikan Nusantara Global. This class consists of 20 students there were 10 males and 10 females.

\section{Instruments}

The instrument used in this research were interviews and observation. Both of those instruments were used to answer the questions of the study dealing with communication problems and the most communication strategy used by EFL students

Furthermore, the phase of doing interview and observation were outlined by sequent. Firstly, The interview is the phase when the researcher conducted the research was in the form of questions concerned with students' opinions related to communication and communication strategy were used. The interview was in the form of an open-ended question. Which is an open-ended question that is one form of a question that sparked a broad and open answer.

In the interview, the researcher would investigate the students about how the students overcome the communication problem and what types of communication strategies that used by students in learning English. The researcher interviewed all students who become a participant in that class and interview by these several steps. Formerly the researcher gave the students' interview questions in the classroom. Then the researcher asks the students to answer those interviews one by one. The last step is for the researcher to collect all students' answers in one file.

Secondly, Besides the interview, the researcher also used observation becomes the data collection technique. The observation is a support series that used in this study. This observation aimed to support the result of the interview. The kinds of observation used were field notes and videotape. Field note was head for note the communication activities of the students during the learning process. The researcher would note all the participants did when they communicate in front of the classroom. While the videotape head for supporting the research, when the researcher forgets about what the participants did she could show on the video that had already been taken.

\section{Data Analysis}

After collection, the data were analyzed according to the taxonomy of communication strategies adopted from Dornyei and Scott's taxonomy of communication strategies (1997), it can be seen in table 1, these were cross-tabulated against proficiency levels to determine the influence of proficiency level on choice and number of communication strategies used. This allowed for preliminary identification of the communication strategies used by the EFL students. Later, with the confirmation of the participants' communication strategies usage (through the post-interview) it was possible to manually count the types and most frequently of Communication Strategies used by EFL students in English Classroom Setting. Furthermore, the display of the data will be based on the questions of the study, i.e., the types of communication strategy used by EFL students, and the most frequent communication strategy used by EFL students. 
Table 1

Type of Communication Strategies Classification

\begin{tabular}{|c|c|}
\hline $\begin{array}{c}\text { Communication Strategies } \\
\text { Classification } \\
\end{array}$ & Description \\
\hline 1. Message abandonment & Leaving a message unfinished because oflanguage difficulty \\
\hline 2. Message reduction & $\begin{array}{l}\text { Reducing the message by avoiding certain language structures or topics } \\
\text { considered for a lack of linguistic resources }\end{array}$ \\
\hline 3. Message replacement & $\begin{array}{l}\text { Substituting the original message with anew one because of not feeling } \\
\text { capable of executing it }\end{array}$ \\
\hline 4. Circumlocution & Exemplifying or describing the propertiesof the target object \\
\hline 5. Approximation & $\begin{array}{l}\text { Using a single alternative lexical item, which shares semantic features } \\
\text { with thetarget word or structure }\end{array}$ \\
\hline 6. Use of all-purpose words & $\begin{array}{l}\text { Tending a general, "empty" lexical item to contexts where specific } \\
\text { words are lacking }\end{array}$ \\
\hline 7. Word-coinage & $\begin{array}{l}\text { Creating a non-existing L2 word by applying a supposed L2 rule to an } \\
\text { existing L } 2 \text { word }\end{array}$ \\
\hline 8. Restructuring & $\begin{array}{l}\text { Abandoning the execution of a verbal plan because of language } \\
\text { difficulties }\end{array}$ \\
\hline 9. Literal Translation & $\begin{array}{l}\text { Translating literally a lexical item, an idiom, a compound word or } \\
\text { structure from L1/L3 to L2 }\end{array}$ \\
\hline 10. Foreignizing & $\begin{array}{l}\text { Using an L1/L3 word by adjusting it to L2 phonology, i.e., with an L2 } \\
\text { pronunciation and/or morphology }\end{array}$ \\
\hline 11. Code Switching & Including L1/L3 words with L1/L3 pronunciation in L2 speech \\
\hline 12. Use of similar-sounding words & $\begin{array}{l}\text { Compensating for a lexical item whose form the speaker is unsure of } \\
\text { with a word whose sounds more or less like target item }\end{array}$ \\
\hline 13. Mumbling & $\begin{array}{l}\text { Swallowing or muttering inaudibly a word whose correct form the } \\
\text { speaker is uncertain about }\end{array}$ \\
\hline 14. Omission & $\begin{array}{l}\text { Leaving a gap when not knowing a word and carrying on as if it had } \\
\text { been said }\end{array}$ \\
\hline 15. Retrieval & $\begin{array}{l}\text { In an attempt to retrieve a lexical item saying a series of incomplete or } \\
\text { wrong forms of structures }\end{array}$ \\
\hline 16. Self-repair & Making self-initiated corrections in one's own speech \\
\hline 16a. Other-repair & Correcting something in the interlocutor's speech \\
\hline 17. Self-rephrasing & $\begin{array}{l}\text { Repeating a term, but not quite as it is, but adding something or } \\
\text { paraphrase }\end{array}$ \\
\hline 18. Over-explicitness (waffling0 & $\begin{array}{l}\text { Using more words to achieve a particular communicative goal than } \\
\text { what is considered normal }\end{array}$ \\
\hline 19. Mime & $\begin{array}{l}\text { Describing whole concepts nonverbally, or accompanying a verbal } \\
\text { strategy with a visual illustration }\end{array}$ \\
\hline 20. Use of fillers & $\begin{array}{l}\text { Using gambits to fill pauses, to stall, and } \\
\text { to gain time in communication }\end{array}$ \\
\hline 21. Self-repetition & Repeating a word or a string of words immediately after they were said \\
\hline 21a. Other-repetition & Repeating something the interlocutor said to gain time. \\
\hline 22. Feigning understanding & $\begin{array}{l}\text { Making an attempt to carry on the conversation in spite of not } \\
\text { understanding something by pretending to understand }\end{array}$ \\
\hline 23. Verbal strategy markers & $\begin{array}{l}\text { Using verbal marking phrases before or after a strategy to signal that the } \\
\text { word or structure does not carry the intended meaning }\end{array}$ \\
\hline 24. Direct appeal for help & Turning to interlocutor for assistance by asking an explicit question \\
\hline 24b. Indirect appeal for help & $\begin{array}{l}\text { Trying to elicit help from the interlocutor indirectly by expressing lack } \\
\text { of a needed L } 2 \text { item }\end{array}$ \\
\hline 25. Asking for repetition & Requesting repetition when not hearing or understanding \\
\hline 26. Asking for clarification & Requesting explanation \\
\hline 27. Asking for confirmation & $\begin{array}{l}\text { Requesting confirmation that one heard or understood something } \\
\text { correctly. }\end{array}$ \\
\hline 28. Guessing & $\begin{array}{l}\text { Guessing is similar to a confirmation request, but the latter implies a } \\
\text { greater degree of certainty, whereas guessing involves real indecision }\end{array}$ \\
\hline
\end{tabular}




\begin{tabular}{|l|l|}
\hline 29. Expressing non-understanding & Expressing that one did not understand something properly \\
\hline 30. Interpretive summary & $\begin{array}{l}\text { Extended paraphrase of the interlocutor's message to check that speaker } \\
\text { has understood correctly }\end{array}$ \\
\hline 31. Comprehension check & Asking questions to check that the interlocutor can follow \\
\hline 32. Own-accuracy check & Checking that what said was correct by asking a question \\
\hline 33. Response: repeat & $\begin{array}{l}\text { Repeating the original trigger or the } \\
\text { suggested corrected form }\end{array}$ \\
\hline 33b. Response: repair & Providing other-initiated self-repaired \\
\hline 33c. Response: rephrase & Rephrasing the trigger \\
\hline 33d. Response: expand & Putting the problem words into a largercontext \\
\hline 33e. Response: confirm & Confirming what the interlocutor has saidor suggested \\
\hline
\end{tabular}

\section{RESEARCH FINDINGS AND DISCUSSION \\ Research Findings}

To classify the types and the most frequent communication strategy used by students, this study used some theories of communication strategies supported by Dornyei \& Scott (1997), Nakatani (2006), Mariani (2010), \& Somsai and Intaraprasert (2011). There were several types of communication strategies used by EFL students during classroom interaction, i.e., Message abandonment, Circumlocution, Asking for repetition, Asking for clarification, Meaning negotiation, and Interaction monitoring.

Here is the explanation of the types of communication strategies used by the EFL students in English Classroom Setting.

\section{Types of communication strategies \\ a) Asking for clarification}

Asking for clarification is a student's language skill. Some students learn it somewhat naturally from watching others manage conversational breakdowns. Other students require direct instruction to manage breakdowns. Asking for clarification was one of the communication strategies used by EFL students in English Classroom setting that happened when both of the students shared their stories with each other in the topic of the presentation dealing with the best friend. Thus, the speaker was asking for clarification about the issues to the interlocutor to make it clear. It was indicated that this communication strategy was used by some students in that class. This type is used by some students when they communicate in the classroom. To understand the students employed asking for clarification as a type communication strategy, see extract 1.

\section{Extract 1: (Observation 2)}

(1) $L$ : We have many story.

(2) $H:$ Tell me about your story

This extract shows the utterances that happen only in two short dialogues, that the speaker informed to interlocutor about their story when the presenting the material, the students did not ask many clarifications because the topic of the presentation was about story of the best friend, honestly, the topic was not really interesting to ask about the clarification. They only try to help when the presenter did not know the vocabulary and did not know. So that, in this case, the researcher only found a single question from student $\mathrm{H}$ who asked for clarification about the story. During the presentation teacher and other students focus on the core material presented by other students.

\section{b) Asking for repetition}

This type of strategy is occasionally used by students when to communicate happened when students did not listen clearly dealing with the choice for the university, they used asking for repetition strategy to make it clear. That type is not used by all of the students but 
only used by some of the students in that class. Because other students sometimes did not really pay attention when other students speak in front of the class, then students who were asked for the repetition only students who really care and pay attention full for the presentation.

Extract 2 shows that the students used of asking for repetition strategy when the students present the material about collage, while some others had a conversation about that topic.

\section{Extract 2: (Observation 3)}

(1) $R$ : Why you choose to study in this college?

(2) $L$ : I would continue my study in UNRAM or UNU but I late to registration.

(3) $R$ : How about you? What is your reason to study here?

(4) $K$ : Because I will to study, e. Ee

(5) $R:$ What?

(6) $K$ : I want to study in Mataram but...

In this phase, the researcher shows the students' interaction active. When the groups discussed in front of the class, other groups try to prepare what would they discuss in front. They arranged the conversation. Then, the student who asked for the repetition is one of the members of the group. Based on the role made by the teacher, the speaker at that time was only the group whose have the chance. During the presentation teacher and other students focus on listening to the discussion. It aimed to make the classroom condition quiet so the group would listen clearly.

\section{c) Circumlocution}

This strategy happens when students ask for clarification about the issues. occur when, in the lack of the desired lexical item to make reference to an object, action, or idea, the learner decides to describe, illustrate or exemplify its properties. Circumlocution was the learner describes the characteristics or elements of the object or action instead of using the appropriate target language (TL) item or structure this is in line with the theory of (Tarone, 1981; Paribakht, 1985; Dörnyei and Kormos, 1998).

Extract 3 shows the use of the Circumlocution strategy occurs when students discuss the topic about their family, in this case, their mother. In extract 3, we see how a mutual agreement on the meaning 'knocker' is established through the joint and coordinated actions of the speaker and interlocutor. The successful communication of the message is collaboratively achieved, with the active participation of both the learner and the interlocutor along with an interactionally created CS episode.

\section{Extract 3: (Observation 3)}

(1) $R$ : How about your mother, do you live with your mother.

(2) B : Yes I live with my mother, but now my mom is die. She has leave from this world.

(3) $L: O h$, really? I'm sorry.

(4) $B$ : It is ok.

In this phase, the researcher shows the students' interaction when the group discussed the topic of family, particularly about the mother, the students feel really enthusiastic about taking part in the discussion. So most students try to describe their mother. As what happened in extract 3, it showed that the students explain and describe the condition of his mother to the interlocutor. Based on extract 3 the researcher conclude the students use the circumlocution strategy.

\section{d) Message abandonment}

The next type of communication strategy used by EFL students in classroom setting was message abandonment. This type of strategy happened when the student begins to talk about a concept, however, it was unable to continue and stops in the middle-utterance. 
Learners try not to talk about the concepts which they find difficult to express. It refers to leaving the message unfinished due to a lack of a structural or linguistic item. message abandonment is used by EFL Students when they feel nervous they leave a message unfinished during communication in classroom presentation, this is in line with Tarone (1981: 287).

Extract 4 shows This extract taken from the conversation among the students in the classroom during which some of the students were asked to discuss a topic in front of the classroom. On this occasion, the topic discussed was classroom activity where the students directly had assignment presentations dealing with the subject course given.

\section{Extract 4: (Observation 2)}

(1) R: Why you choose to study in this college?

(2) L: I will study, I will to learn ee memperdalam English skill

Based on the utterances shown in extract 10, shows that EFL students used an alternative expression in terms of questions that may not express exactly. eg. why you choose to study in this collect?. Student L reply by saying ' I will study; the student L in that part has still lacked a reason for his reply. Student L conveyed a message due to language difficulty. The language difficulty is the student's biggest problem, thus, the student conveyed hedging to avoid language difficulties.

\section{e) Meaning Negotiation}

Negotiation of meaning occurs in the interactions as a communication strategy to make meaning comprehensible. In a conversation, speakers and interlocutors may employ negotiation of meaning strategy to achieve mutual understanding. Negotiation of meaning is important in language acquisition and second or foreign language learning. With the use of negotiation of meaning, speakers and interlocutors can avoid misunderstanding and communication breakdowns. This qualitative study examined the ways in which learners of English employed negotiation of meaning strategies in conversation performed by EFL students in the classroom setting. Based on observation 3, speaker and hearer giving help and asking help to others, the students also try to make some self-correction and other corrections. To make it clear, see extract 5 .

Extract 5 shows most of the students, employed a meaningful negotiation strategy when they were asking about help, giving help to others, self-correction, and other corrections. This extract was taken from the third observation, where the activity was in a group discussion. The data shows that there were some students seems more active and some part of them were not.

\section{Extract 5: (Observation 3)}

(1) $N$ : Where is your village location?

(2) $T$ : Location emm,

(3) $N$ : The location of your village, where?

(4) T: In Batukliang

Based on extract 5, some other students did not know what they want to say, while the other students tried to give some help about how the students hard to mention what they want to say. The speaker tries to take part in the discussion, and if there were something wrong, they try to correct each other and give help to others. This fact, make the classroom condition balance

\section{f) Monitoring Interaction}

The last communication strategy used by EFL students in communication when the students gave attention to the explanation of interlocutors This is an unequal role of the participants (speaker and interlocutor) in the classroom setting are one of the most striking features of any classroom, they are asymmetrical. In language classrooms, the teacher 
orchestrates the interaction'. speaker control patterns of communication by managing both the topic of conversation and turn-taking, while students typically take cues from the teacher through whom pointed directly in the classroom. if there were some mistakes, the speaker tried to give feedback and directly corrected it.

Extract 6 shows that the teacher directs the question in the plot of the discussion. Teachers, through their unique status in a classroom, and by the power and authority, they have, control both the content and procedure of a lesson, as well as controlling participation. This type of communication strategy is used when one of the students is told about something then other students try asking the clarification or explanation about the issue that has already been informed. In the data of the study, there were about $60 \%$ of the students used that strategy monitoring interaction in the classroom setting.

\section{Extract 6: (Observation 1)}

(1) B: How to say hello when we meet with new people, it's mean how to greet someone who we meet for the first time?

(2) S: If you introduce yourself for the first time, maybe you can say $\mathrm{Hi}$, you can to be close to him.

(3) $H$ : Can we say how do you do?

(4) $S:$ Yes, we can say it.

(5) H : Beside whats up, how is it going, any other informal greeting to greet our friend?

(6) $S:$ We can say long time no see.

(7) $H:$ No, is not long time no see.

Based on the discussion above, the students would ask about something if they were not understanding about something, then the students who asked the question will directly give the clarification or the explanation that had already been asked by other students. Even though the answer was not covered answer of the question, however, the students just try to expose their languages based on their own skill. in this part, the teacher also sometimes gives an explanation to students if there are unclear issues.

\section{The most Frequently communication strategy used by EFL students}

The types of communication strategies that are usually used by students are asking for clarification, message abandonment, and meaning negotiation.

\section{a) Asking for clarification}

Asking for clarification is one of the communication strategies used by students in communication. When communicating with other students ask for clarification about the issues. It was found that this communication strategy was used by some students in that class. There were about $60 \%$ of the students used that strategy in communication. This type of communication strategy is used by some of the students when they communicate in the classroom.

Extract 1 shows the use of asking for clarification strategy. The communication among the students shows the use of this communication strategy. This was the conversation among the students in the classroom during one of the students' presentations in front of the classroom. The topic of the presentation is the best friend. The students directly present the material about best friends.

\section{Extract 1: (Observation 2)}

(1) $L:$ We have many story.

(2) $H$ : Tell me about your story.

In this phase, the researcher shows the students' interaction was not too much. When the presenter present the material, the students did not ask for much clarification because the topic of the presentation is about best friend, that topic not really interesting to asking about the clarification. The researcher only found a single question from the students who asked 
about the story. During the presentation teacher and other students focus on listening to the presenter present her material. They only try to help when the presenter did not know the vocabulary and did not know what to say.

\section{b) Message abandonment}

The next type of communication strategy was Message abandonment. This type of strategy is sometimes used by students when communicating in English classroom setting. The student begins to talk about a concept but is unable to continue and stops in midutterance. The message abandonment is leaving a message because of the language difficulty especially when the students feel nervous, this is in line with Tarone (1981: 287).

Extract 4 shows the use of the message abandonment strategy. The communication among the students shows the use of this communication strategy. The example of the conversation used is the conversation that takes place in the classroom during some of the students are asked to discuss a topic in front of the classroom. Extract 4 was taken from the second observation while discussing the topic of college. In this case, the students directly present the material about collage.

\section{Extract 4: (Observation 2)}

(1) R: Why you choose to study in this college?

(2) L: I will study, I will to learn ee memperdalam English skill

Based on the conversation in extract 4, one of the students tries to give an explanation about the topic, however, in that part was still a lack of understanding. Actually, she know what she wants to talk about, but when she conveyed her message, the message was not conveyed it was caused by language difficulty. The language difficulty is the biggest problem for students. Many students can speak or communicate but are hindered by the language. Moreover, the message conveyed by students was hard to catch by others because the message conveyed was not clear.

\section{c) Meaning negotiation}

This is the next type of communication strategy. Meaning negotiation strategy is the strategy that has these several criteria. There are asking about help, giving help to others, selfcorrection, and other corrections. This strategy is the most strategy used by students in EFL learning. It proofed by the result of the observation. Starting from the first observation until the third observation this type is usually used by students in communication. When communicating with others, students ask for help and give help when other did not know what to say. Moreover, besides giving help and asking help from others, the students also try to make some self-correction and other corrections. The correction means that when the students communicate. When the students communicate their words or material wrong they would correct it directly. For the display of the data, see extract 5.

Extract 5 shows this type of communication strategy used by some of the students when communicating with others. When discussed in the classroom the researcher shows the interaction among the students. There were some students seems more active and there were some students not active. This extract was taken from the third observation, in the third observation the activity was group discussion. hen discussion running, each student tries to take the role in the discussion, and if there were something wrong they try to correct each other and give help to others.

\section{Extract 5: (Observation 3)}

(1) $N$ : Where is your village location?

(2) $T$ : Location emm,

(3) $N$ : The location of your village, where?

(4) T: In Batukliang 
Based on the researcher's opinion, in this conversation the student give some help to other friends. Because he thinks his friend did not really know about the answer to the question asked, therefore the student give help to answer the question. As what the definition of meaning negotiation, the researcher categorized this extract include in meaning negotiation strategy.

\section{Discussion}

The data displayed on the findings show that there were several types of communication strategies used by EFL students. Those types were classified based on the theory of Dornyei \& Scott (1997), Nakatani (2006), Somsai \& Intaraprasert (2011) Mariani (2010). However, this study mostly used Dornyei \& Scott (1997) theory to identify the types of communication strategy in EFL classroom setting. They are asking for clarification, requesting an explanation, asking for repetition, circumlocution, message abandonment, meaning negotiation, and interaction monitoring.

Based on the data finding of the study, there are various types of communication strategy used by EFL students in English Classroom Setting, i.e., first, type of strategy supported by Dornyei \& Scott (1997), 1) Message Abandonment; this type of strategy used by students when they begins to talk about a concept but it is unable to continue and stops in mid-utterance. The message abandonment leaves a message because of language difficulty. That is what the students sometimes do when communicating, especially when the students feel nervous they leave a message unfinished, 2) Circumlocution; this type happen when the students describe the characteristics or elements of the object or action instead of using the appropriate target language (TL) item or structure ("She is, uh, smoking something. I don't know what's its name. In this case, the students would be exemplifying or describing the properties of the target object, 3) asking for repetition; this type of strategy happened when students did not listen clearly, they would be asked about the repetition. This type is not used by all of the students but only used by some of the students in class, 4) Asking for Clarification; Asking for clarification is one of the communication strategies used by students in communication. When communicating with other students ask for clarification about the issues. It was found that this communication strategy was used by some students in that class. There were about $60 \%$ of the students used that strategy in communication. This type of communication strategy is used by some of the students when they communicate in the classroom.

Secondly, in the data finding, there are two types of communication strategy used by EFL students based on the clarification from Mariani (2010), i.e., 1) meaning negotiation; this type of communication strategy happen in the classroom setting when one of the student asking for help, giving help, self-correction, and other corrections. These strategies were the most frequently used by EFL students in the utterances, it happens when others did not know what to say, 2) interaction monitoring; interaction monitoring is one of the communication strategies used by students in the classroom setting when students gave attention to the explanation of interlocutors some mistakes occurred, the hearers try to forgive and correct it.

\section{CONCLUSION}

To sum up, communication strategies remain an important element used by the student in EFL classroom setting. Compensatory strategies, in particular, will undoubtedly promote students' communicative competence. Teachers can play an important role in conveying communication strategies to students and thereby assisting them to practice the target language. Data analysis concludes that there some type and the most frequent communication strategy used by EFL students in the classroom setting, i.e., there are seventh types of communication strategies i.e.: Asking for clarification, requesting an explanation, asking for 
repetition, circumlocution, message abandonment, meaning negotiation, and interaction monitoring. While the most frequent communication strategy used by students were three types i.e., Asking for clarification, message abandonment, and meaning negotiation. Finally, this study claims that the practice of presentation and, discussion in English class requires a single competence that is made up of or could be considered to integrate a set of competencies that include, for instance, competence in both the source and the target languages.

\section{REFERENCES}

Abousenna, M. (1995). "Opening Speech. Global Age: Issues in English Language Education". Proceedings of 13th National Symposium on English Language Teaching. March 30 April 1, 1993. CEDELT, Ain Shams University.

Ary, D., Jacobs, Lucy C., \& Asghar, R. (2010). Introduction to Research in Education, 8th Edition. Canada: Nelson Education Ltd.

Brown, D. H., \& Abeywickrama, P. (2019). Language Assessment: Principles and Classroom Practices (2nd Edition). Pearson Education ESL.

Dörnyei Z., \& Scott. (1997). On the Teachability of Communication Strategies. TESOL Quarterly,29(1), pp.55-85.

Dörnyei, Z., \& Kormos, J. (1998). Problem-Solving Mechanisms in L2 Communication: A Psycholinguistic Perspective. Studies in Second Language Acquisition, 20, 349-385.

Floreddu, P. B., \& Cabiddu, F. (2016). Social media communication strategies. Journal of Services Marketing, 30(5), 490-503. doi:10.1108/JSM-01-2015-0036.

Mariani, L. (2010). Communication strategies: Learning and teaching how to manage oral interaction. NA: Learning Path-Tante Vie Per Imparare.

Mauranen, A. (2015). English as a global Lingua Franca: changing language in changing global academia. In Murata, K. (ed.) Exploring ELF in Japanese Academic and Business Contexts. Amsterdam: John Benjamins. 29-46.

Nakatani, Y. (2006). Developing an Oral Communication Strategy Inventory. Modern Language Journal, 90, 151-168.

Paribakht, T. (1985). Strategic Competence and Language Proficiency. Applied Linguistics, 6, 132-146. http://dx.doi.org/10.1093/applin/6.2.132

Somsai, S., \& Intaraprasert, C. (2011). Strategies for Coping with Face-to-Fac Oral Communication Problems Employed by Thai University Students Majoring in English. In Zhao, Tao. 2013. Communication in EFL Students Majoring Tourism (Unpublished doctoral dissertation). Suranaree University of Technology, Nakhon Ratchasima, Thailand. Retrieved from: http://sutir.sut.ac.th:8080/sutir/bitstream /123456789/4541/2/Fulltext.pdf

Sukmawati, F. (2016). Students' Speaking Problems and Factors Causing It. Jurnal Logika, $16(1), 1-11$.

Tarone, E. (1981). Some Thought on the Notion of Communication Strategy. TESOL Quarterly, 15(3), pp. 285-295.

Willis, J. (1996). A Framework for Task-Based Learning. Harlow: Longman.

Yule, G. (2010). The Study of Language. New York. Cambridge University Press. 